\title{
Cytotoxic and antiviral potentials of Euphorbia milii var. splendens leaf against Peste des petits ruminant virus
}

\author{
Sadia Chaman ${ }^{1}$, Farrakh Zia Khan ${ }^{2}$, Rabia Khokhar ${ }^{1}$, Husnul Maab ${ }^{1}$, Shaista \\ Qamar $^{1}$, Sahar Zahid ${ }^{3}$, Mobasher Ahmad ${ }^{1}$, Khalid Hussain ${ }^{1}$ \\ ${ }^{1}$ Institute of Pharmaceutical Sciences, University of Veterinary and Animal Sciences, ${ }^{2}$ Punjab University College of Pharmacy, \\ The University of Punjab, ${ }^{3}$ Leads College of Pharmacy, Leads University, Lahore, Pakistan
}

*For correspondence: Email: Sadia.chaman@uvas.edu.pk; Tel: +92-042- 99214341

\begin{abstract}
Purpose: To determine the cytotoxic and antiviral potentials of Euphorbia milii var. splendens leaf against Peste des petits ruminants virus (PPRV).

Methods: The methanol extract, as well as $n$ - hexane, chloroform, ethyl acetate, and $n$ - butanol fractions of E. milii leaves were screened for cytotoxic and antiviral activities against PPRV using Vero cell line and 3-(4,5-dimethylthiazol-2-yl)-2, diphenyltetrazolium bromide (MTT) assay.

Results: Non-cytotoxic concentrations with cell survival rate (CSP) greater than $50 \%$ were considered virucidal. Methanol extract and fractions produced significant $(p<0.05)$ effects at all test concentrations against PPRV. The $50 \%$ cytotoxic concentration $\left(C_{50}\right)$ calculated was $\leq 25 \mu \mathrm{g} / \mathrm{mL}$ for extract and fractions. In antiviral assay, ethyl acetate, $n$-hexane, and $n$-butanol fractions at all test concentrations ranging from $1.56-800 \mu \mathrm{g} / \mathrm{mL}$ were non-virucidal; even at their non-cytotoxic concentrations these fractions did not show antiviral activities. However, the methanol extract and its chloroform fractions showed significant $(p<0.05)$ virucidal potential.

Conclusion: The results suggest that further isolation of antiviral constituents from the fractions may open new horizons for the development of new antiviral agents.
\end{abstract}

Keywords: Antiviral, Cytotoxic, Euphorbia milii, Vero cell, Peste des petits ruminants virus

\begin{abstract}
This is an Open Access article that uses a fund-ing model which does not charge readers or their institutions for access and distributed under the terms of the Creative Commons Attribution License (http://creativecommons.org/licenses/by/4.0) and the Budapest Open Access Initiative (http://www.budapestopenaccessinitiative.org/read), which permit unrestricted use, distribution, and reproduction in any medium, provided the original work is properly credited.

Tropical Journal of Pharmaceutical Research is indexed by Science Citation Index (SciSearch), Scopus, International Pharmaceutical Abstract, Chemical Abstracts, Embase, Index Copernicus, EBSCO, African Index Medicus, JournalSeek, Journal Citation Reports/Science Edition, Directory of Open Access Journals (DOAJ), African Journal Online, Bioline International, Open-J-Gate and Pharmacy Abstracts
\end{abstract}

\section{INTRODUCTION}

The viral disease, Peste des petits caused by Peste des petits ruminant virus (PPRV) is havoc for ruminants in endemic areas. Fever, diarrhea, mouth ulcers, anorexia, nasal discharges and pneumonia are major symptoms observed in ruminants [1]. Attenuated PPRV vaccine is only approach, to control spread of Peste des petits disease. Therefore, it is important to discover new antiviral agents with broad therapeutic efficacy, less side effects enormities and cost effectiveness [2]. Literature reported that many phytochemicals i.e. lignans, tannins, flavonoids, saponins and proteins endures anti-viral properties [3]. These therapeutically active phytoconstituents treat viral infections either by directly killing virus, while others boost immunity against infections [4]. 
Many medicinal plants need thorough scrutinization against different viruses to discover potent antiviral agents. One such example is Euphorbia milii; an ornamental plant and commonly known as 'crown of thorn'. It is not used traditionally in Pakistan but in China, it is used to treat abdominal edema and liver disorders [5]. However, its latex remain effective folk remedy for body strains in Nepal [6]. Methanol extract of E. milii leaves exhibit pronounced analgesic effect [7]. Phytochemical analysis revealed occurrence of lupeol, $\beta$-amyrin, euphol, cycloartenol, $\beta$-sitosterol, and flavonoids which fortify its grade among medicinal plants [8]. In the current investigation, methanol extract/fractions of $E$. milii leaves have been screened for cytotoxic and antiviral potential by using in vitro cell culture techniques.

\section{EXPERIMENTAL}

\section{Collection and authentication of plant material}

Euphorbia milii leaves were collected from the botanical garden of Institute of Pharmaceutical Sciences, UVAS, Lahore during the month of March. The specimen was identified and authenticated by Prof. Dr. Zaheer Ahmed from Department of Botany, GCU, Lahore. Voucher specimen of plant was acquiesced to Sultan Ayub Herbarium, Government College University, Lahore under voucher no. 2012.

\section{Preparation of extract and fractions}

Maceration process was used to prepare methanol extract of leaves. Then methanol extract was extracted sequentially using solvents in order of increasing polarity. Solvents were removed from successive fractions using rotary evaporator at $40{ }^{\circ} \mathrm{C}$. Two fold Serial dilutions $(1.56,3.12,6.25,12.5,25,50,100,200,400$ and $800 \mu \mathrm{g} / \mathrm{mL}$ ) of methanol extract and the fractions were prepared by mixing with M199 media (Fetal bovine serum $1 \%$ ) [9].

\section{Vero cells seeding in culture plates}

Purified PPRV and Vero cell lines were obtained from Quality Operation Laboratory, University of Veterinary and Animal Sciences, Lahore, Pakistan. Virus Tissue culture infective dose $\left(\mathrm{TCID}_{50}\right)$ was calculated [10]. Dye exclusion method was used to evaluate viability of cells. Cell viability (V) was calculated as in Eq 1.

$V(\%)=A / B \times 100$ where $A=$ number of viable cells $/ \mathrm{m}$ and $B=$ total number of cells $/ \mathrm{mL}$.

Culture media (M199) and fetal bovine serum were used to prepare cell suspension $(100 \mu \mathrm{L}$ of $1 \times 10^{5}$ ) and sown in each well of 96 well plates for both anti-viral and cytotoxicity assay. Plates were incubated with $5 \% \mathrm{CO}_{2}$ at $37{ }^{\circ} \mathrm{C}$ for $72 \mathrm{~h}$. Confluency (80-90\%) of cells in each plate was maintained by regular monitoring under microscope [11].

\section{Cytotoxicity assay}

Cytotoxicity assay was performed according to method of Freshney [11]. Confluent cells were used in assay. Exhausted media was removed from cells. Sterilized phosphate saline was used to wash cells. Then, fresh M199 media $(100 \mu \mathrm{L})$ was again added to cells. Separate wells were used to add test materials $(100 \mu \mathrm{L})$ followed by incubation at $37{ }^{\circ} \mathrm{C}$ for six days with $5 \% \mathrm{CO}_{2}$. DMSO (20\%) with media (M199) served as negative control whereas Vero cells with media (M199) were considered as positive control.

\section{Anti-viral assay}

Procedures of cell culturing and washing were similar as mention in cytotoxicity assay. Different concentrations of extract and fractions were mixed separately with PPRV and plates were incubated at $4{ }^{\circ} \mathrm{C}$ for $20-30$ min. Similarly, all test materials were mixed with Vero cells and incubated with $5 \% \mathrm{CO}_{2}$ at $37{ }^{\circ} \mathrm{C}$. Culture Media (M199) along with Vero cell served as positive control; whereas culture media (M199) along with Vero cells and PPRV served as negative control [12].

\section{MTT (3-(4, 5-dimethylthiazol-2-yl)-2,diphenyl- tetrazolium bromide) assay}

MTT assay was conducted according to protocol by Twentyman and Luscombe [13]. Media was removed from culture plates after incubation of 56 days. From each well, cells were washed with PBS and impregnated in newly prepared media (M199). In each well 100 $\mathrm{\mu l} 0.5 \%$ MTT dye was mixed and incubated for $3-4 \mathrm{~h}$ at $37^{\circ} \mathrm{C} .100 \mu \mathrm{L}$ of $5 \%$ DMSO was added in culture plates after removing exhausted media. Culture plates were again incubated for two hours at $3{ }^{\circ} \mathrm{C}$. ELISA reader was used to measure absorbance $(A)$ at $570 \mathrm{~nm}$. For both antiviral and cytotoxic assay, cell survival rate (CSP) was determined as in $\mathrm{Eq}$ 2.

$\operatorname{CSP}(\%)=\{(\mathrm{At}-\mathrm{Anc}) / \mathrm{Apc}\}$ 
where At, Anc and Apc are absorbance of test, negative control and positive control samples, respectively.

\section{Statistical analysis}

The results are expressed as mean \pm standard deviation (SD). SPSS version 22 was used for data analysis. Analysis of variance (ANOVA and post-hoc test were used for data analysis. Differences were considered significant at $p<$ 0.05 .

\section{RESULTS}

The results of cytotoxic and antiviral activity of methanol extract and fractions ( $n$-hexane, chloroform, ethyl acetate and $n$-butanol) of $E$. milii leaves are summarized in Tables 1 and 2. Non-cytotoxic concentrations with CSP greater than $50 \%$ were considered virucidal. Methanol extract and fractions produced significant $(p<$
0.05) effects at all tested concentrations against PPRV.

It was observed from both assays that the methanol extract and fractions (n-hexane, chloroform, ethyl acetate and $n$-butanol) behave differently at different concentrations. The cytotoxic analysis portrayed that methanol extract and all fractions at concentrations ranging from 1.56 - $25 \mu \mathrm{g} / \mathrm{mL}$ were non-cytotoxic for Vero cells. However, at these concentrations CSP was greater than $50 \%$. The toxic potential of the tested materials was ascertained at concentrations ranging from $50-800 \mu \mathrm{g} / \mathrm{mL}$. $50 \%$ cytotoxic concentration $\left(\mathrm{CC}_{50}\right)$ calculated for methanol extract and each fraction was $\leq 25$ $\mu \mathrm{g} / \mathrm{mL}$ (Table 1).

In antiviral assay, ethyl acetate, $n$-hexane and $n$ butanol fractions at all tested concentrations ranging from $1.56-800 \mu \mathrm{g} / \mathrm{mL}$ were non-virucidal, even at their non-cytotoxic concentrations these fractions did not show antiviral activities.

Table 1: Cytotoxic activities of methanol extract and fractions of $E$. milii leaf

\begin{tabular}{|c|c|c|c|c|c|}
\hline \multirow{2}{*}{$\begin{array}{l}\text { Extract/fraction } \\
\text { concentration }(\mu \mathrm{g} / \mathrm{ml})\end{array}$} & \multicolumn{5}{|c|}{ Mean cell survival (\%) } \\
\hline & $\begin{array}{c}\text { Methanol } \\
\text { extract }\end{array}$ & $\begin{array}{c}\text { n-Hexane } \\
\text { fraction }\end{array}$ & $\begin{array}{c}\text { Chloroform } \\
\text { fraction }\end{array}$ & $\begin{array}{c}\text { Ethyl acetate } \\
\text { Fraction }\end{array}$ & $\begin{array}{c}\text { n-Butanol } \\
\text { fraction }\end{array}$ \\
\hline 1.56 & $95.33 \pm 2.20$ & $96.00 \pm 1.00$ & $97.66 \pm 1.5$ & $92.00 \pm 1.00$ & $92.00 \pm 1.00$ \\
\hline 3.12 & $91.00 \pm 1.0$ & $91.00 \pm 2.00$ & $83.33 \pm 1.50$ & $83.22 \pm 1.50$ & $83.33 \pm 1.00$ \\
\hline 6.25 & $77.66 \pm 1.50$ & $81.00 \pm 1.00$ & $79.00 \pm 1.00$ & $81.00 \pm 1.50$ & $81.00 \pm 1.00$ \\
\hline 12.5 & $66.33 \pm 1.10$ & $64.00 \pm 1.00$ & $66.00 \pm 1.00$ & $66.66 \pm 1.50$ & $66.66 \pm 2.60$ \\
\hline $25^{\star *}$ & $54.00 \pm 1.00$ & $53.00 \pm 1.00$ & $52.00 \pm 1.00$ & $52.00 \pm 1.50$ & $52.00 \pm 1.00$ \\
\hline 50 & $48.00 \pm 1.00$ & $45.66 \pm 1.50$ & $47.00 \pm 1.00$ & $44.66 \pm 1.50$ & $44.66 \pm 1.00$ \\
\hline 100 & $43.00 \pm 1.00$ & $38.00 \pm 1.00$ & $44.00 \pm 1.00$ & $41.00 \pm 1.00$ & $41.00 \pm 1.00$ \\
\hline 200 & $41.00 \pm 1.00$ & $37.00 \pm 1.50$ & $41.66 \pm 1.50$ & $36.33 \pm 2.00$ & $36.33 \pm 1.00$ \\
\hline 400 & $34.33 \pm 1.50$ & $37.00 \pm 1.00$ & $43.00 \pm 1.00$ & $32.67 \pm 3.00$ & $32.67 \pm 1.00$ \\
\hline 800 & $34.00 \pm .00$ & $34.00 \pm 1.50$ & $31.33 \pm 1.50$ & $31.33 \pm 2.00$ & $31.33 \pm 1.50$ \\
\hline${ }^{*} P$-value & $<0.05$ & $<0.05$ & $<0.05$ & $<0.05$ & $<0.05$ \\
\hline
\end{tabular}

Data are presented as mean $\pm S D$. ${ }^{*}$ Statistically different at $p<0.05 ;{ }^{\star *} C_{50}=$ cytotoxic concentration which cause $50 \%$ inhibition

Table 2: Antiviral activities of methanol extract and fractions of $E$. milii leaf

\begin{tabular}{lcccrc}
\hline $\begin{array}{l}\text { Extract/fraction } \\
\text { concentration } \\
(\boldsymbol{\mu g} / \mathrm{ml})\end{array}$ & $\begin{array}{c}\text { Methanol } \\
\text { extract }\end{array}$ & $\begin{array}{c}\text { n-Hexane } \\
\text { fraction }\end{array}$ & $\begin{array}{c}\text { Chloroform } \\
\text { Fraction }\end{array}$ & $\begin{array}{c}\text { Ethyl } \\
\text { acetate } \\
\text { Fraction }\end{array}$ & $\begin{array}{c}\text { M-Butanol } \\
\text { fraction }\end{array}$ \\
\cline { 2 - 6 } & $8.00 \pm 0.57$ & $21.00 \pm 0.57$ & $41.0 \pm 0.57$ & $4.00 \pm 0.57$ & $31.00 \pm 0.57$ \\
1.56 & $65.00 \pm 0.57^{* *}$ & $22.66 \pm 0.88$ & $46.00 \pm 0.57$ & $5.00 \pm 0.57$ & $34.33 \pm 1.20$ \\
3.12 & $61.00 \pm 0.57^{* *}$ & $23.00 \pm 1.15$ & $52.66 \pm 1.85^{* *}$ & $7.00 \pm 0.57$ & $38.00 \pm 0.57$ \\
6.25 & $54.00 \pm 0.57^{* *}$ & $31.00 \pm 0.57$ & $53.00 \pm 0.57^{* *}$ & $42.00 \pm 0.57$ & $42.00 \pm 0.57$ \\
12.5 & $52.00 \pm .033^{* *}$ & $31.00 \pm 0.57$ & $52.00 \pm 0.57^{* *}$ & $48.00 \pm 0.57$ & $46.00 \pm 0.57$ \\
25 & $47.00 \pm 0.57$ & $33.00 \pm 0.57$ & $47.00 \pm 0.57$ & $44.60 \pm 0.88$ & $37.00 \pm 0.57$ \\
50 & $41.00 \pm 0.57$ & $28.00 \pm 0.57$ & $36.00 \pm 0.57$ & $37.00 \pm 0.57$ & $36.00 \pm 0.57$ \\
100 & $41.00 \pm 0.88$ & $37.00 \pm 0.57$ & $32.00 \pm 0.57$ & $35.00 \pm 0.57$ & $22.66 \pm 1.45$ \\
200 & $31.00 \pm 0.88$ & $33.00 \pm 0.57$ & $28.00 \pm 0.57$ & $31.00 \pm 0.57$ & $29.00 \pm 0.57$ \\
400 & $16.00 \pm 0.57$ & $43.00 \pm 0.57$ & $18.00 \pm 0.57$ & $24.00 \pm 0.57$ & $27.33 \pm 0.88$ \\
800 & $<0.05$ & $<0.05$ & $<0.05$ & $<0.05$ & $<0.05$ \\
${ }^{*}$ P-value & $<$ &
\end{tabular}

Data results are presented as Mean $\pm S D$. All groups are statistically different and difference is considered significant at ${ }^{*} p<0.05 ;{ }^{* *}$ virucidal concentrations 
The results also revealed that methanol extract was toxic for PPRV at non-cytotoxic concentrations 3.12 - $25 \mu \mathrm{g} / \mathrm{mL}$, where CSP was greater than $50 \%$. Chloroform fraction showed antiviral effect at concentration range 6.12-25 $\mu \mathrm{g} / \mathrm{mL}$. In both of the assays, decrease in CSP with an increasing concentration was apparent (Table 2).

\section{DISCUSSION}

Single stranded RNA genome (16kb) of PPRV encrypts six structural proteins such as large polymerase protein (L), matrix protein $(M)$, nucleoprotein $(\mathrm{N})$, fusion protein $(\mathrm{F})$, hemagglutinin protein $(\mathrm{H})$ and phosphoprotein $(\mathrm{P})$. These proteins help virus to attach with cellular membrane of host and get control of cellular functions [1]. Plants contain phytochemicals which are therapeutically effective against virus or having synergistic effects with other antiviral agents [14]. Phytochemical investigation revealed that E. milii leaves are composed of $\beta$-amyrin, euphol, lupeol, $\beta$-sitosterol, cycloartenol, flavonoids, tannins and terpenoids $[8,15,16]$ which are reported as potent antiviral agents. Literature exposed anti-viral activity of these compounds against various RNA viruses creating an ideal scenario to probe against RNA containing PPRV. Literature also confirmed the presence of polyphenols in methanol extract/fractions of $E$. milii leaves [17]. These compounds might be responsible for cytotoxic activity of the methanol extract /fractions at concentrations ranging from $50-800 \mu \mathrm{g} / \mathrm{mL}$.

The antiviral effect of methanol extract and chloroform fraction was also observed against PPRV. The effect could be linked to the presence of quercetin, rutin, myricetin and kaempferol [17] because various studies revealed that these flavonoid possess anti-viral activities against different viruses i.e. HIV and influenza virus $[18,21,22]$. These compounds inactivate or inhibit virus by making complexes with RNA viral proteins. Moreover, Ingenol esters might cause PPRV replication inhibition by down regulation of different viral receptors as observed in Jatropane esters isolated from Euphorbia amygdaloide [22,23].

In present study, the significant virucidal activity depicted only by methanol extract and chloroform fraction which indicates the presence of potential antiviral compounds. The same activity appears to be lacking in others fractions. The potential cytotoxic and antiviral compounds in these extracts/ fractions might be responsible for these activities. The isolation and characterization of these compounds can open new horizons in drug discovery

\section{CONCLUSION}

Euphorbia milii leaf possesses good cytotoxic and virucidal activities against PPRV. These activities might be due to the flavonoid-rich composition of the leaf, but further isolation and characterization of the virucidal compounds are required to better understand their underlying mechanism of action.

\section{DECLARATIONS}

\section{Acknowledgement}

The authors are thankful to Dr Imran Altaf for providing lab facilities in the University of Veterinary and Animal Sciences, Lahore, Pakistan.

\section{Conflict of interest}

No conflict of interest is associated with this work.

\section{Contribution of authors}

The authors declare that this research work was done by the authors listed in this article and all liabilities pertaining to claims related to the contents will be borne by them. Sadia Chaman, Farrakh Zia Khan, Mobasher Ahmad and Khalid Hussain conceived and designed the study, Rabia Khokhar and Saher Zahid collected and analyzed the data, while Husnul Maab and Shaista Qamar wrote the manuscript.

\section{Open Access}

This is an Open Access article that uses a funding model which does not charge readers or their institutions for access and distributed under the terms of the Creative Commons Attribution License (http://creativecommons.org/licenses/by/ 4.0) and the Budapest Open Access Initiative (http://www.budapestopenaccessinitiative.org/rea d), which permit unrestricted use, distribution, and reproduction in any medium, provided the original work is properly credited.

\section{REFERENCES}

1. Esmaelizad M, Jelokhani-Niaraki S, Kargar-Moakhar $R$. Phylogenetic analysis of peste des petits ruminants virus (PPRV) isolated in Iran based on partial sequence 
data from the fusion (F) protein gene. Turk J Biol 2011; 35(1): 45-50.

2. Esimone CO, Grunwald T, Wildner O, Nchinda G, Tippler $B$, Proksch $P$, Ueberla $K$. In vitro pharmacodynamic evaluation of antiviral medicinal plants using a vector-based assay technique. J Appl Microbiol. 2005; 99(6): 1346-55.

3. Kratz JM, Andrighetti-Fröhner CR, Kolling DJ, Leal $P C$, Cirne-Santos CC, Yunes RA, Nunes $R J$, Trybala E, Bergström T, Frugulhetti I C. Anti-HSV-1 and anti-HIV-1 activity of gallic acid and pentyl gallate. Mem Inst Oswaldo Cruz. 2008; 103(5): 437-42.

4. Bergner $P$. Antiviral botanicals in herbal medicine. Medical Herbalism. 2005; 14(3): 1-12.

5. Delgado IF, De-Carvalho RR, De-Oliveira ACAX, Kuriyama SN, Oliveira-Filho EC, Souza CAM, Paumgartten FJR. Absence of tumor promoting activity of Euphorbia milii latex on the mouse back skin. Toxicol Lett 2003; 145(2): 175-180.

6. Manandhar NP. Plants and people of Nepal: Timber Press; 2002; pp 2-50

7. Rauf A, Muhammad N, Qaisar M, Uddin G, Hussain I. Preliminary antinociceptive studies of methanol extract of Euphorbia milii. Middle-East J Med Plants Res. 2012; 1(3): 68-70.

8. Pancorbo S, Hammer RH. Preliminary phytochemical investigation of Euphorbia milii. J Pharm Sci. 1972; 61(6): 954-7.

9. Bhanuprakash V, Hosamani M, Balamurugan V, Singh R, Swarup $D$. In vitro antiviral activity of Eugenia jambolana plant extract on buffalopox virus: Conventional and QPCR methods. Int J Trop Med. 2007; 2(1): 3-9.

10. Reed LJ, Muench H. A simple method of estimating fifty per cent endpoints. Am J Epidemiol. 1938; 27(3): 493-7.

11. Freshney RI. Culture of animal cells: a manual of basic technique and specialized applications: John Wiley \& Sons; 2015.

12. Birch JR, Onakunle Y. Biopharmaceutical proteins. Therapeutic Proteins: Springer; 2005. p. 1-16.

13. Twentyman PR, Luscombe M. A study of some variables in a tetrazolium dye (MTT) based assay for cell growth and chemosensitivity. Br J Cancer. 1987; 56(3): 279.
14. Mohamed IET, Nur E, Abdelrahman MEN. The antibacterial, antiviral activities and phytochemical screening of some Sudanese medicinal plants. Eurasia J Biosci. 2010; 4.

15. Błasiak J, Jałoszynski P, Trzeciak A, Szyfter K. In vitro studies on the genotoxicity of the organophosphorus insecticide malathion and its two analogues. Mutat Res Genet Toxicol Environ Mutagen. 1999; 445(2): 275-83.

16. Rauf A, Khan A, Uddin N, Akram M, Arfan M, Uddin G, Qaisar M. Preliminary phytochemical screening, antimicrobial and antioxidant activities of Euphorbia milli. PJPS. 2014; 27(4).

17. Wyatt $R$, Sodroski J. The HIV-1 envelope glycoproteins: fusogens, antigens, and immunogens. Sci. 1998; 280(5371): 1884-8.

18. Ali A, Akhtar N, Khan BA, Khan MS, Rasul A, Khalid N, Waseem K, Mahmood T, Ali L. Acacia nilotica: a plant of multipurpose medicinal uses. J Med Plant Res. 2012; 6(9): 1492-6.

19. Intizar M, Ahmad M, Anjum A, Hanif A. Comparative efficacy of peste des petits ruminants (PPR) vaccines available in Pakistan in sheep and goats. Pak Vet $\mathrm{J}$. 2009; 29(4): 202-5.

20. Chuanasa T, Phromjai J, Lipipun V, Likhitwitayawuid K, Suzuki M, Pramyothin P, Hattori M, Shiraki K. Antiherpes simplex virus (HSV-1) activity of oxyresveratrol derived from Thai medicinal plant: mechanism of action and therapeutic efficacy on cutaneous HSV-1 infection in mice. Antivir. Res. 2008; 80(1): 62-70.

21. Badar N, Iqbal Z, Khan MN, Akhtar MS. In Vitro and In Vivo Anthelmintic Activity of Acacia nilotica (L.) Willd. Ex Delile Bark and Leaves. Pak Vet J. 2011; 31(3): 185191.

22. Serkedjieva J, Ivancheva S. Antiherpes virus activity of extracts from the medicinal plant Geranium sanguineum L. J Ethnopharmacol. 1998; 64(1): 59-68.

23. Opferkuch $H$, Hecker $E$. On the active principles of the spurge family (Euphorbiaceae). J Cancer Res Clin Oncol. 1982; 103(3): 255-268. 